\title{
Pénzmosás compliance az ügyvédi tevékenység körében Kozák Andrea*
}

A pénzmosás megelözésével kapcsolatosan a gazdasági élet valamennyi szereplőjére számos kötelezettség vonatkozik, azonban ezek közül is kiemelkedó és speciális szerepe van álláspontom szerint az ügyvédeknek, ezért jelen tanulmányban a kifejezetten ügyvédekre háruló feladatok, kötelezettségek kerülnek bemutatásra. A pénzmosás compliance tekintetében az ügyvédek szerepe kettös, hiszen egyrészt saját tevékenységük vonatkozásában minden ügyvédnek feladata a pénzmosás megelözése és megakadályozása, ugyanakkor jogi tanácsadással, okiratszerkesztéssel mások számára is segítséget nyújthatnak a compliant müködésben.

Kulcsszavak: Pénzmosás, compliance, ügyvéd, bejelentés

\section{Money laundering compliance with the lawyer's practice}

All actors of economic life are subject to a number of obligations in connection with the prevention of money laundering. However, the lawyers also have, in my view, a prominent and a special role, therefore the tasks and obligations specifically assigned to lawyers are presented in this study. The lawyers have a dual role regarding money laundering compliance, as on the one hand, all lawyers have the task of preventing and deterring money laundering in relation to their own activities, but they can also assist others in complient operations by providing legal advice and drawing up documents.

Key words: Money laundering, compliance, lawyer, notification

DOI: $10.32980 / M J S z .2021 .1 .956$

\section{Bevezetés}

"A pénzmosás aktualitása örök érvényü ... a pénzmosás elleni joganyag egy dinamikusan fejlődő komplex jogterületté vált"1 ${ }^{\prime \prime}$ melyet igazol egyrészt a pénzmosás, mint búncselekmény tényállásának folyamatos változása, pontositása, másrészt igazolja a pénzmosás megelőzésével kapcsolatos szabályrendszer, jogszabály folyamatos változása is.

A téma pontosabb megértéséhez elsőként nélkülözhetetlen a compliance, a pénzmosás és a pénzmosás compliance fogalmának tisztázása, rövid bemutatása. „A compliance röviden "megfelelést” jelent, egyrészt a különböző jogszabályi előírásoknak, másrészt a belső, a vállalat által felállított - részben jogszabályokon,

\footnotetext{
* Ügyvéd

${ }^{1}$ Jacsó Judit: A pénzmosás elleni fellépés dimenziói Európában: múlt, jelen és jövő; In: Kiss Valéria (szerk.) Kriminológiai Közlemények 72. Válogatás a 2012-ben tartott tudományos ülések előadásaiból, Magyar Kriminológiai Társaság Budapest, 2013. 47.o.
} 
részben erkölcsi-etikai alapokon nyugvó - szabályoknak." "A compliance munka egy sajátos megközelítés a kockázatok azonosítására, belső kontrollfolyamatok kialakítására és életbe léptetésére, amelyek együttesen képesek csökkenteni a releváns szabályoknak, jogi előirásoknak való meg nem felelés kockázatát." ${ }^{3}$

A „legáltalánosabb értelemben a pénzmosás fogalma alá tartoznak azok a magatartások, amely által az elkövető a bűncselekmény elkövetéséből származó bevételek („piszkos pénzek") létezését, e bevételek forrását vagy jogellenes felhasználását elleplezi, azzal a céllal, hogy a legalitás látszatát keltse, és mint látszólag legális vagyont áramoltassa be a gazdasági és pénzügyi világba." ${ }^{4}$

„A pénzmosás egy olyan háromlépcsős folyamat, melynek lépései egyidejüleg, de akár külön-külön is megvalósíthatók. Első lépcső az elhelyezés, melynek célja a készpénz könnyebben kezelhető, kevésbé feltűnő eszközökre váltása azáltal, hogy elhelyezésre kerül a pénzügyi rendszerben. Az ügyvédek elsődleges célpontjai lehetnek ezen lépés megvalósításának az ügyfelek pénzének letéti kezelése kapcsán. A második lépcső a rétegzés, az illegális jövedelemnek a forrástól való elkülönítése a pénzügyi tranzakciók összetett rendszerével, egymásra rétegződésével. A harmadik lépcső az integrálás, vagyis a mosott jövedelem visszajuttatása a gazdaságba oly módon, mintha legális üzleti tevékenységből származna." ${ }^{5}$ A pénzmosás büntetőjogi tényállását a Btk. 399-400. §-a határozza meg.

A pénzmosás compliance a fenti két fogalom ötvözeteként határozható meg akként, hogy az a pénzmosás megelőzésével kapcsolatos nemzetközi, európai uniós és nemzeti szabályozások gyüjtőfogalma, vagyis a pénzmosás megelőzésével kapcsolatos szabályoknak való megfelelés. A pénzmosás compliance-hez tartozó intézkedések alapvetően a preventív jellegű eszközök közé illeszthetők.

Témánk szempontjából irányadó és egyik leglényegesebb jogszabály a pénzmosás és a terrorizmus finanszírozása megelőzéséről és megakadályozásáról szóló 2017. évi LIII. törvény (továbbiakban: Pmt.), melynek 1. § (1) bekezdésének I) pontja egyértelmúvé teszi, hogy hatálya a Magyarországon székhellyel rendelkező ügyvédekre és ügyvédi irodákra is kiterjed. Fentieket kiegészítve, szintén lényeges szabályokat tartalmaz az ügyvédi tevékenységről szóló 2017. évi LXXVIII. törvény (továbbiakban: Üttv.), valamint a pénzmosás és a terrorizmus finanszírozása megelőzéséről és megakadályozásáról szóló 2017. évi LIII. törvényben és az Európai Unió és az ENSZ Biztonsági Tanácsa által elrendelt pénzügyi és vagyoni korlátozó intézkedések végrehajtásáról szóló 2017. évi LII. törvényben meghatározott kötelezettségek teljesítéséről szóló 10/2019. (VI. 24.) MÜK szabályzat (továbbiakban: Szabályzat). Ezen jogszabályi rendelkezések összevetésével, egymás

\footnotetext{
${ }^{2}$ Ambrus - Farkas: A compliance alapkérdései. Az etikus vállalati működés elmélete és gyakorlata, Budapest, Wolters Kluwer Hungary Kft., 2019., 19.o.

* Köszönetemet szeretném kifejezni Prof. dr. Jacsó Judit egyetemi tanárnak a témáért, a tanulmány összeállításában nyújtott segítségéért és támogatásáért.

3 Ajánlás a Compliance funkció számára. Belső Ellenőrök Magyarországi Közhasznú Szervezete. https://szabalyzatok.hu>images ajanlas_compliance Letöltve: 2020. március 21. 3.o.

4 Jacsó Judit: A pénzmosás compliance hazai és európai dimenzióban a társadalmi innováció tükrében; In: Miskolci Jogi Szemle 2019/2. különszám 1. kötet 394.o.

${ }^{5}$ Patyi Gergely: Ügyvédség a köz- és magánjog határán (doktori értekezés); Pázmány Péter Katolikus Egyetem Jog és Államtudományi Kar Jog- és Államtudományi Doktori Iskola; 2012. 163.o.
} 
kiegészítésével kívánom bemutatni az ügyvédi tevékenység kapcsán irányadó pénzmosás compliance szabályokat. A téma feldolgozása során kiemelt szerepet kapott a Budapesti Ügyvédi Kamara által közzétett Pénzmosás elleni szabályozás gyakorlati útmutatója is, továbbá kitérek majd a FATF 2012-ben közzétett, egységes szerkezetbe foglalt Negyven Ajánlására, valamint a IV. Pénzmosási Irányelv ${ }^{6}$ rendelkezéseire, mely 2018. évben módosításra7 került.

\section{Pénzmosás complience az ügyvédi tevékenységben}

A tanulmány további részében az ügyvédeket terhelő, a pénzmosás megelőzésére irányuló preventív intézkedések bemutatására kerül sor az irányadó jogszabályi rendelkezések, szabályzat és ajánlás bemutatásával.

2.1. Ügyfél-átvilágítás. Az ügyfél-átvilágítás az ügyfél azonosítását, az ügyfél kockázati besorolását, a személyazonosság igazoló ellenőrzését, az üzleti kapcsolat és az ügyleti megbízás céljának és jellegének megismerését, folyamatos figyelemmel kísérését jelenti. Az ügyfél-átvilágításon belül az ügyfél azonosítása egy szükebb kategóriát takar, mely a Pmt.-ben meghatározott adatok visszakereshető módon történő rögzítését jelenti. A Pmt. az ügyfél-átvilágítás, míg az Üttv. az ügyfél azonosításának szabályait részletezi.

Az ügyfél-átvilágítási és bejelentési kötelezettség az ügyvédet akkor terheli, ha bizalmi vagyonkezelési tevékenységet végez, vagy ha pénz és értéktárgy letéti kezelését végzi, illetve a következő jogügyletek előkészítésével és végrehajtásával összefüggésben végez ügyvédi tevékenységet:

a) gazdasági társaságban vagy egyéb gazdálkodó szervezetben lévő vagyonrész, részesedés tulajdonának átruházása,

b) ingatlan tulajdonának átruházása,

c) gazdasági társaság vagy egyéb gazdálkodó szervezet alapítása, müködtetése, megszünése,

d) bizalmi vagyonkezelési szerződés vagy bizalmi vagyonkezelés létesítésére irányuló egyoldalú jognyilatkozat,

e) ingó vagyonelem, különösen pénzeszköz, pénzügyi eszköz ellenérték nélkül történő átruházása.

Kötelező az ügyfél-átvilágítás a négymillió-ötszázezer forintot elérő vagy meghaladó összegü ügyleti megbízás teljesítésekor. Ebben az esetben az átvilágítási kötelezettség kiterjed az egymással ténylegesen összefüggő, több ügyleti

\footnotetext{
${ }^{6}$ Az Európai Parlament és a Tanács (EU) 2015/849 irányelve (2015. május 20.) a pénzügyi rendszerek pénzmosás vagy terrorizmusfinanszírozás céljára való felhasználásának megelőzéséről, a 648/2012/EU európai parlamenti és tanácsi rendelet módosításáról, valamint a 2005/60/EK európai parlamenti és tanácsi irányelv és a 2006/70/EK bizottsági irányelv hatályon kívül helyezéséről (EGT-vonatkozású szöveg) HL L 141, 5.6.2015.6.5., 73-117. o.

${ }^{7}$ Az Európai Parlament és a Tanács (EU) 2018/843 irányelve (2018. május 30.) a pénzügyi rendszerek pénzmosás vagy terrorizmusfinanszírozás céljára való felhasználásának megelőzéséről szóló (EU) 2015/849 irányelv, valamint a 2009/138/EK és a 2013/36/EU irányelv módosításáról (EGT-vonatkozású szöveg), HL L 156, 2018.6.19., 43-74. o.
} 
megbízásra, ha ezek együttes értéke eléri a négymillió-ötszázezer forintot, ilyenkor az átvilágítást azon ügyleti megbízás elfogadásakor kell végrehajtani, amellyel az ügyleti megbízások együttes értéke eléri a fenti összeget. Szintén kötelező ügyfélátvilágítást alkalmazni az üzleti kapcsolat létesítésekor, a pénzmosásra vagy terrorizmus finanszírozására utaló adat, tény vagy körülmény felmerülése esetén, ha átvilágításra még nem került sor; vagy ha a korábban rögzített ügyfél-azonosító adatok valódiságával vagy megfelelőségével kapcsolatban kétség merül fel; valamint ha az ügyfél-azonosító adatokban bekövetkezett változás kerül átvezetésre és kockázatérzékenységi megközelítés alapján szükséges az ügyfél-átvilágítás ismételt elvégzése.

Az ügyfél-átvilágítási kötelezettség akkor terheli az ügyvédet, ha a fenti, tehát a Pmt. 6. § (1) bekezdése és 73. § (1) bekezdése szerinti feltételek együttesen állnak fenn.

A IV. Pénzmosási Irányelv preambuluma ${ }^{8}$ ezzel kapcsolatosan kitér arra, hogy a jogi hivatások képviselőinek indokolt az irányelv hatálya alá tartozniuk, ha pénzügyi vagy társasági ügyletekben vesznek részt, ideértve az adótanácsadást is, mivel ezekben az esetekben a legnagyobb a kockázata annak, hogy a jogi hivatások képviselőinek a szolgáltatásaival visszaélnek a büntetendő cselekményből származó jövedelem tisztára mosása céljából. Mentességet kell azonban nyújtani az igazságszolgáltatási eljárás előtt, az eljárás folyamán és azt követően, vagy az ügyfél jogi helyzetének tisztázása során szerzett információkra vonatkozó bejelentési kötelezettség alól. A jogi tanácsadásra ezért továbbra is vonatkoznia kell a szakmai titoktartási kötelezettségnek, kivéve, ha a jogi hivatás képviselője pénzmosási tevékenységekben vesz részt, ha a jogi tanácsadás nyújtása pénzmosás céljára történik, vagy ha a jogi hivatás képviselője tudatában van annak, hogy az ügyfél a jogi tanácsot pénzmosás érdekében kéri.

Amennyiben a fenti feltételek fennállnak, úgy az ügyvéd a megbízási szerződés megkötése, illetve tartós megbízás esetén a megbízás teljesítése előtt egyszerüsített vagy fokozott ügyfél-átvilágítást végez el, valamint meghatározza, hogy az ügyfél milyen kockázati szintbe tartozik, és azt a megbízási szerződésben vagy külön íven rögzíti.

Az ügyfél kockázati csoportba sorolásához nyújtanak segítséget a pénzmosás és a terrorizmus finanszírozása megelőzéséről és megakadályozásáról szóló 2017. évi LIII. törvény, valamint az Európai Unió és az ENSZ Biztonsági Tanácsa által elrendelt pénzügyi és vagyoni korlátozó intézkedések végrehajtásáról szóló 2017. évi LII. törvény alapján elkészítendő belső szabályzat kötelező tartalmi elemeiről szóló 21/2017. (VIII. 3.) NGM rendelet mellékleteiben meghatározott - különösen az ügyfél- és földrajzi - kockázati tényezők.

Magasabb kockázatra vonatkozó tényező lehet például, ha az üzleti kapcsolat szokatlan körülmények között zajlik; vagy az ügyfél magas kockázatot jelentő földrajzi területen rendelkezik lakóhellyel; vagy a bizalmi vagyonkezelők; vagy a társaság tulajdonosi szerkezete a társaság üzleti tevékenységének jellegéhez képest szokatlannak vagy túlzottan összetettnek tűnik. Magas földrajzi kockázati tényező lehet például az olyan ország, amelyik nem rendelkezik a pénzmosás és a terrorizmus

\footnotetext{
${ }^{8}$ 2015/849/EU irányelv Preambulum 9. pont
} 
finanszírozása elleni küzdelemmel összefüggésben hatékony rendszerekkel; vagy ahol magas szintü a korrupció vagy magas az egyéb büntetendő cselekmények száma; vagy az Unió vagy az ENSZ BT által megállapított szankciók hatálya alá tartozik; vagy közismerten terroristák tevékenységét finanszírozza, vagy területén ismert terrorista szervezetek működnek.

2.1.1. Egyszerüsített ügyfél-átvilágítás ${ }^{9} A z$ ügyvéd a saját kockázatértékelésén alapuló, alacsony kockázatú esetekben egyszerüsített ügyfél-átvilágítást végez, melynek keretében rögzíti az ügyfél személyazonosító/azonosító adatait, beszerzi a személyazonosság igazoló ellenőrzéséhez szükséges okiratok másolatát, vagy adatlekérést végez közhiteles nyilvántartásból és annak eredményét rögzíti; elvégzi a tényleges tulajdonos kilétével kapcsolatos eljárásokat, valamint a kiemelt közszereplői jelleg meghatározásával kapcsolatos eljárásokat, továbbá teljesíti a Pmt.-ben meghatározott monitoring kötelezettségeket.

$A z$ egyszerüsített ügyfél-átvilágítás módját arra az esetre, ha az ügyfél személyesen nincs jelen, a Pmt. 15 . § (3) bekezdése határozza meg, ide sorolva többek között az elektronikus hírközlő eszközt, a postai úton küldött okiratokat, azonosított elektronikus levelezési címről biztonságosan küldött okiratmásolatokat, valamint az ügyfél által hozzáférhetővé tett elektronikus dokumentumokat is. ${ }^{10}$

Az ügyvéd az egyszerűsített ügyfél-átvilágítás eredményeként az ügyfél/fél, illetve a tényleges tulajdonos azonosító adatait rögzíti a nyilvántartásában; a megbízás adatait rögzíti az Üttv. 53. §-a szerinti - az ügyekről vezetett nyilvántartásában, a tényleges tulajdonosi információk központi nyilvántartása számára továbbítja az adatokat, továbbá a megbízási szerződésben vagy külön íven rögzíti az ügyfélnek (félnek) a tényleges tulajdonosi, valamint kiemelt közszereplöi minőség hiányára vonatkozó nyilatkozatát, az ügyfél-átvilágítás eredményének más szolgáltató részére való továbbításához való esetleges hozzájárulását.

Amíg korábban a Pmt. 7. § (2) bekezdésben meghatározott valamennyi adatot rögzíteni kellett az ügyfél-átvilágítás eredményeként, az Afad-törvény ${ }^{11}$ alapján módosított rendelkezések szerint jelenleg ${ }^{12}$ a természetes személy családi és utónevét, állampolgárságát, lakcímét (tartózkodási helyét) és azonosító okmányának típusát és számát rögzíteni kell, míg kockázatérzékenységi megközelítés alapján a születési családi és utónevet, születési helyet és időt, anyja születési nevét rögzíteni lehet. Ugyanez rögzíthető a jogi személyekkel vagy jogi személyiséggel nem rendelkező szervezettel kapcsolatosan, jelenleg a nevet, székhelyet és cégjegyzék számot/nyilvántartási számot rögzíteni kell, míg kockázatérzékenységi megközelítés alapján a fötevékenységet, a képviseletre jogosult nevét és beosztását, a kézbesítési megbízott adatait és adószámot rögzíteni lehet.

Ha a természetes személy ügyfél vagy fél képviseletében meghatalmazott jár el, a meghatalmazó azonosítása a meghatalmazás alapján is elvégezhető, ha a

\footnotetext{
${ }^{9}$ Pmt. 15. §

${ }^{10}$ Pmt. 15. $\S(3)$ bekezdés

${ }^{11}$ a pénzügyi és egyéb szolgáltatók azonosítási feladatához kapcsolódó adatszolgáltatási háttér megteremtéséről és működtetéséről szóló 2021. évi XLIII. törvény

12 2021. május 22-i hatállyal
} 
meghatalmazást ügyvéd ellenjegyezte, közjegyző készítette, a meghatalmazó aláíását közjegyző hitelesítette, vagy a meghatalmazást az aláirás helye szerint illetékes magyar külképviseleti hatóság hitelesítette vagy felülhitelesítette, illetve azt Apostille tanúsítvánnyal látták el és tartalmazza a személyazonosításra alkalmas adatokat. Ebben az esetben ugyanis az ügyfél-átvilágítási intézkedéseket a meghatalmazást ellenjegyző ügyvéd, vagy hitelesítő közjegyző köteles elvégezni.

Az egyszerüsített ügyfél-átvilágítás nevében ugyan egyszerüsített, azonban láthatjuk, hogy ténylegesen számos intézkedést, ellenőrzési kötelezettséget foglal magában, mely jelentős adminisztrációs terhet jelent az ügyvédek számára.

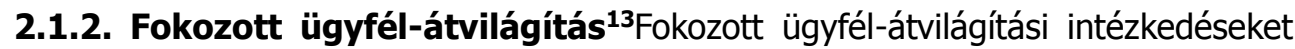
köteles alkalmazni az ügyvéd, ha az ügyfél magas kockázatú. Magas kockázatúnak kell tekinteni az ügyfelet ha az ügyfél stratégiai hiányosságokkal rendelkező, kiemelt kockázatot jelentő harmadik országból származik, a belső szabályzatban rögzített egyéb esetekben, távoli azonosítás esetén, ha az ügyfél vagy tényleges tulajdonosa kiemelt közszereplő vagy a kiemelt közszereplő közeli hozzátartozója vagy kiemelt közszereplővel közeli kapcsolatban álló személy, továbbá ha az ügyfél az Afadtörvény alapján "megbízhatatlan” minősítésű tényleges tulajdonosi adatokkal rendelkező adatszolgáltatónak minősül, valamint a felügyeletet ellátó szerv által kiadott útmutatóban meghatározott egyéb esetekben.

A fokozott ügyfél-átvilágítás során az ügyvéd az egyszerüsített ügyfél-átvilágítási intézkedéseken túlmenően a jogi személy, egyéb szervezet nyilvántartásból származó kivonat, folyamatban levő bejegyzés esetén a létesítő okirat megtekintésével azonosítja, nyilatkoztatja a jogi személy, egyéb szervezet ügyfelet (felet) a tényleges tulajdonosának adatairól, valamint a nyilatkozat valóságát a rendelkezésre bocsátott okiratok megtekintésével ellenőrzi is, továbbá nyilatkoztatja az ügyfelet (felet) az ügylet tárgyát képező pénzeszköz vagy vagyontárgy forrására nézve, valamint a nyilatkozat valóságát a rendelkezésére bocsátott okiratok megtekintésével ellenőrzi.

Az ügyvéd a fokozott ügyfél-átvilágítás eredményeként az ügyfél (fél) és a megbízás adatait rögzíti a nyilvántartásban; a tényleges tulajdonos adatait továbbítja a központi nyilvántartás számára; a megbízási szerződésben ${ }^{14}$ vagy külön íven rögzíti az ügyfél (fél) arra vonatkozó nyilatkozatát, hogy a természetes személy a tényleges tulajdonos nevében vagy érdekében jár-e el, hogy az ügyfél (fél/tényleges tulajdonos) kiemelt közszereplőnek, kiemelt közszereplő közeli hozzátartozójának vagy kiemelt közszereplővel közeli kapcsolatban álló személynek minősül-e, azzal, hogy rögzíteni kell a kiemelt közszereplő nevét, e minőségét alátámasztó körülményeket, valamint a fennálló kapcsolatot, továbbá az ügyfél-átvilágítás eredménye más szolgáltató részére való továbbításához való esetleges hozzájárulását is rögzíteni kell.

A fokozott ügyfél-átvilágítás legszembetűnőbb eltérése az egyszerüsítetthez képest, hogy nyilatkoztatni szükséges az ügyfelet a pénzeszköz vagy a vagyontárgy

\footnotetext{
${ }_{13}$ Pmt. 16-17. §

${ }^{14}$ Kivéve, ha a megbízási szerződés tartalmi elemeit az ügyvéd által ellenjegyzett okirat tartalmazza
} 
forrására nézve is, s ekörben nem elegendő egy nyilatkozat, hanem annak valóságát ellenőrizni is szükséges.

2.2. Az ügyfél azonosítása és a személyazonosság igazoló ellenőrzése. Az ügyfél azonosítása és a személyazonosság igazoló ellenőrzése az ügyfél átvilágítási folyamat első lépése. Az ügyvéd az azonosítás során köteles a természetes személy személyazonosító adatait, ${ }^{15}$ valamint a cég azonosítására szolgáló adatait ${ }^{16}$ a megbízási szerződés megkötését megelőzően az erre a célra rendszeresített formanyomtatványon és az ügyvéd által vezetett - Pmt. 33. § szerinti nyilvántartásban rögzíteni.

Az ügyvéd az adatok egyezőségének és a bemutatott okmányok érvényességének ellenőrzése érdekében a személyi adat- és lakcím-, a jármúvezetői engedély-, az útiokmány- és a központi idegenrendészeti nyilvántartásból elektronikus úton adatokat igényelhet. Ugyanakkor a közhiteles nyilvántartásba való bejegyzés alapjául szolgáló okirat ellenjegyzését megelőzően köteles a nyilvántartásokból adatokat igényelni, kivéve, ha az adatigénylésre harminc napon belül már sor került. Ebben az esetben mellőzhető a másolat készítése az okmányokról. Ha az elektronikus adatigénylés technikai okokból nem lehetséges, az a megbízási szerződés megkötésének és a jognyilatkozatok okiratba foglalásának nem akadálya; az akadály megszűnését követően haladéktalanul el kell végezni az ellenőrzést és az okiratot csak ezt követően, és ennek eredményétől függően lehet ellenjegyezni. A jogi személyt vagy más szervezetet az ügyvéd a nyilvántartó hatóság nyilvántartása vagy az abból származó kivonat alapján azonosítja.

Az okmányok és okiratok bemutatása történhet az eredeti okmány bemutatásával vagy hitelesített másolatának (vagy az eredeti okiratnak) eljuttatásával, valamint előzetesen auditált elektronikus hírközlő eszköz útján is.

Az elektronikus hírközlő eszköz akkor használható, ha az informatikai biztonság követelményeinek megfelel, biztosítja az ügyvédi titok védelmét és lehetővé teszi, hogy a rögzített hang- és képfelvétel tárolható, visszakereshető és egyértelmüen beazonosítható legyen.

A Magyar Ügyvédi Kamara küldöttgyülése a személyes megjelenés nélküli azonosítás módját meghatározta, az alkalmazható elektronikus hírközlő eszközöket a Magyar Ügyvédi Kamara elnöke auditálta, s meghatározta az azonosítás során használható egyes elektronikus hírközlő eszközöket:

a) a Skype szoftver bármely operációs rendszerre kiadott, 8.50.0.38 vagy újabb verziója,

b) a Skype for Business szoftver bármely operációs rendszerre kiadott, 16.0.4795.1000 vagy újabb verziója,

c) a Microsoft Teams szoftver Windows és macOS operációs rendszerre kiadott 1.2.00.4664 vagy újabb verziója, az iOS operációs rendszerre kiadott 1.0.80 vagy

${ }^{15}$ Személyazonosító adatok: családi és utónév, születési családi és utónév, állampolgárság, születési hely és idő, anyja születési neve, lakcím, ennek hiányában tartózkodási hely, azonosító okmány típusa és száma.

${ }^{16}$ Cég azonosítására szolgáló adatok: név, rövidített név, székhely, külföldi székhelyű vállalkozás esetén magyarországi fióktelep címe, főtevékenység, képviseletre jogosult neve és beosztása, kézbesítési megbízott neve és lakcíme, cégjegyzékszám, nyilvántartási szám, bejegyző határozat száma; adószám. 
újabb verziója, az Android operációs rendszerre kiadott 1416/1.0.0.2019071503 vagy újabb verziója,

d) a bluejeans.com honlapon keresztül elérhető videotelefon-szolgáltatás,

e) a Google Hangouts Meet azon szolgáltatása, amely a kép- és hang egyidejü rögzítését és mentését az alkalmazáson belül biztosítja,

f) a LogMeIn https://gotomeeting.com weboldalon elérhető azon GoToMeeting szolgáltatása, amely a kép- és hang egyidejü rögzítését és mentését az alkalmazáson belül biztosítja,

g) a Cisco azon v39.0 vagy magasabb verziószámú Webex Meetings szolgáltatása, amely a kép- és hang egyidejü rögzítését és mentését az alkalmazáson belül biztosítja,

h) az ACPM IT Tanácsadó Kft. https://dataroom.acpmit.com/index.php/login weboldalon elérhető ACPM SecureOffice 1.0.1. vagy magasabb verziószámú szolgáltatása,

i) a Zoom Meetings 5.4.2. vagy magasabb verziószámú szolgáltatása végponti titkositás (end-to-end encryption) alkalmazásával.

A távazonosítás biztonságos lefolytatását számos garanciális szabály biztosítja, így különösen, hogy a távazonosítás folyamatát rögzíteni kell, az azonosított személyt kifejezetten nyilatkoztatni kell, hogy a távazonosításhoz hozzájárul-e. Az azonosítás során az azonosításhoz felhasznált okmányoknak minden, rögzítendő adatot tartalmazó oldalát fel kell mutatni a kamerának és az okmányt akként kell mozgatni, hogy az azon található biztonsági elemek és rögzítendő adatok felismerhetőek legyenek, továbbá az azonosított személynek megfelelően megvilágítva, úgy kell a kamerába néznie, hogy az ügyvéd meg tudjon győződni a felmutatott okmányon szereplő fénykép és az azonosított természetes személy arcképének, nemének, illetve hozzávetőleges korának egyezőségéről is, emellett az okmány felmutatása mellett a rögzítendő adatokat szóban is közölnie kell. Fentieken túlmenően a távazonosítás során alkalmazni kell az egyszerüsített, illetve a fokozott ügyfélátvilágításra vonatkozó rendelkezéseket is.

2.3. Tényleges tulajdonos azonosítása. $A z$ ügyfél-átvilágítás során a természetes személy ügyfél köteles nyilatkozni, ha tényleges tulajdonos nevében vagy érdekében jár el, nyilatkoznia kell továbbá arról is, hogy a tényleges tulajdonos kiemelt közszereplőnek minősül-e, s amennyiben igen, a jogszabály mely pontja alapján. A Pmt. rendelkezései szerint a szolgáltató köteles a tényleges tulajdonos adatait a tényleges tulajdonosi információk központi nyilvántartása számára továbbítani.

A hivatkozott nyilvántartást a pénzügyi és egyéb szolgáltatók azonosítási feladatához kapcsolódó adatszolgáltatási háttér megteremtéséről és működtetéséről szóló 2021. évi XLIII. törvény teremtette meg. A jogszabály rendelkezései szakaszosan lépnek hatályba. A tényleges tulajdonosi nyilvántartásba történő adatfeltöltésre vonatkozó rendelkezések 2021. október 1. napján fognak hatályba lépni, mely szerint a számlavezető a nyilvántartásaiban rendelkezésre álló adatokat minden naptári hónap utolsó napját követő 5 napon belül továbbítja a nyilvántartó szervnek; ekkor a $\Pi T$ index értéke 10 pont. Amennyiben a tényleges tulajdonosi viszonyokat érintő érdemi eltérés jelzésére kerül sor a nyilvántartó szerv felé, úgy a 
TT index 1 vagy 2 ponttal csökkentésre került, s amennyiben az 8 pont alá csökken "bizonytalan”, amennyiben 6 pont alá "megbízhatatlan” minősítést kapnak az adatszolgáltató tényleges tulajdonosi adatai. Ha az adatszolgáltató megerősíti vagy módosítja az adatait, a nyilvántartást vezető szerv a TT index értékét ismét 10 pontra módosítja. A "megbízhatatlan" minősítésű adatszolgáltatót az ügyvédnek - a 2022. július 1-i hatálybalépést követően - a Pmt. 10. § (1) bekezdés b) pontja alapján magas kockázatúnak kell tekintenie, s ennek megfelelően kell az ügyfél-átvilágítási intézkedéseket is végrehajtania. A „megbízhatatlan” minősítésű tényleges tulajdonosi adatokkal rendelkező adatszolgáltató által kezdeményezett, négymillióötszázezer forintot elérő összegü ügylet teljesítését az ügyvéd - s a Pmt. szerinti többi szolgáltató is - köteles megtagadni.

2022. január 1. napjától a szolgáltató - s így az ügyvéd is - a Pmt.-ben előírt ügyfél-átvilágítási intézkedések vagy az adatellenőrzési kötelezettségek teljesítése érdekében ingyenesen hozzáférhet az adatszolgáltatók tényleges tulajdonosi nyilvántartásban tárolt adataihoz, s fenti kötelezettségei teljesítéséhez köteles is lesz adatot igényelni.

2.4. Ügylet azonosítása. Az ügyvéd az ügyfél-átvilágítás során az üzleti kapcsolatra vonatkozóan köteles rögzíteni a szerződés típusát, tárgyát és időtartamát, az ügyfél kockázati besorolását, a teljesítés körülményeit, az üzleti kapcsolat célját és tervezett jellegét. ${ }^{17}$

Fentieken túl - kockázatérzékenységi megközelítés alapján - kéri a pénzeszközök forrására vonatkozó információk rendelkezésre bocsátását, és ezen információk igazoló ellenőrzése érdekében a pénzeszközök forrására vonatkozó dokumentumok bemutatását is.

A Magyar Nemzeti Bank 6/2019. (IV. 1.) Számú ajánlása a pénzügyi intézmények és közvetítőik részére tartalmaz előirásokat, azonban azok az ügyvédek ügyletazonosítási kötelezettsége során is irányadóak lehetnek. Rögzítésre került az ajánlásban, hogy a szolgáltatónak az ügyletben szereplő pénzeszközök legális forrásból való származására vonatkozóan is be kell szereznie adatot, ennek keretében azonban nem fogadhat el olyan információt, amely nem a forrás eredetére, hanem a felhasználás céljára irányul; az a tény, hogy a forrás megtakarításból származik, nem alkalmas a forrás igazolására. A szolgáltatónak minden esetben össze kell hasonlítania a beszerzett adatokat az ügyfélről rendelkezésre álló egyéb adatokkal. Az ajánlás mellékletében felsorolásra kerültek a szokatlan ügyletek felismerésének szempontjai is, így például ha a gazdasági társaság tulajdonosának vagy képviselőjének megjelenése, kommunikációja összeegyeztethetetlen a társaság tevékenységével; vagy olyan ügyfél, aki nem működik együtt ahhoz, hogy az ügyfél-átvilágítás során előírt adatok, dokumentumok beszerzésre kerüljenek tőle, vagy a pénzeszköz forrására kétséges tartalmú nyilatkozatot tesz.

A FATF 40 ajánlás 11. pontja szerint is különös figyelmet kell fordítani minden összetett és szokatlanul nagy ügyletre, minden olyan szokatlan ügyleti szerkezetre, amelyek nem szolgálnak nyilvánvaló gazdasági, vagy láthatóan jogszerü célt. Az ilyen

\footnotetext{
${ }^{17}$ Pmt. 10. §
} 
ügyletek hátterét és célját a lehetséges mértékben vizsgálni kell.

\section{5. Üzleti kapcsolat folyamatos figyelemmel kísérése (monitoring),} adatváltozások követése. Az ügyvéd köteles az üzleti kapcsolatot folyamatosan figyelemmel kísérni annak megállapítása érdekében, hogy az adott ügylet összhangban áll-e az ügyfélről a jogszabályok alapján rendelkezésére álló adataival és ez alapján szükség van-e az ügyféllel szemben pénzmosás megelőzésével kapcsolatos intézkedések végrehajtására. ${ }^{18}$

Az ügyvéd köteles biztosítani, hogy az ügyfél-átvilágítás alapján rendelkezésre álló adatok és okiratok, valamint az ügyfél kockázati szintjének meghatározása naprakészek legyenek; köteles továbbá ügyfele figyelmét írásban is felhívni az adatokban bekövetkezett változások közlésének kötelezettségére. Erre irányuló ellenőrzési kötelezettségét magas kockázat esetén évente, alacsony kockázat esetén legalább ötévente köteles elvégezni. Ha az ellenőrzés során kétsége merül fel az adatok és a nyilatkozatok naprakészségét illetően, akkor ismételten elvégzi az ügyfélátvilágítási intézkedéseket.

2.6. Bejelentés. Az ügyvéd a pénzmosásra, terrorizmus finanszírozására, vagy dolog büntetendő cselekményből való származására utaló adat, tény, körülmény felmerülése esetén köteles a területi ügyvédi kamara elnöke által kijelölt személynek haladéktalanul írásban bejelentést tenni. A Pmt. azonban nem konkretizálja, hogy mely esetekben merül fel bejelentés alapjául szolgáló adat, tény, körülmény, annak felismerése és eldöntése az ügyvédet terheli.

Az ügyvéd védelemmel ellátott elektronikus üzenet formájában a területi ügyvédi kamara elnöke által kijelölt felelös személynek jelenti be, ha a megbízással összefüggésben pénzmosásra vagy terrorizmus finanszírozására utaló adat, tény vagy körülmény merül fel. $A$ bejelentés beérkezéséről a területi kamara elektronikus üzenet formájában haladéktalanul értesíti a bejelentést továbbító ügyvédet. $A z$ ügyvéd alkalmazottja a bejelentést a munkáltatói jogokat gyakorló ügyvédnél teszi meg, s a munkáltatói jogokat gyakorló ügyvéd továbbítja a bejelentést a területi kamarának. Az ügyvédi iroda alkalmazottja a taggyűlés által kijelölt személynek tesz bejelentést.

A területi ügyvédi kamara elnöke kijelöli azt a személyt, aki az érkezett bejelentést a pénzügyi információs egységnek haladéktalanul továbbítja. A pénzügyi információs egység, a Pénzmosás és Terrorizmusfinanszírozása Elleni Iroda a Nemzeti Adó- és Vámhivatal szervezetén belül, de a pénzmosás megelőzésével kapcsolatos feladatkörében függetlenül működik.

Lényeges hangsúlyozni, hogy a bejelentési kötelezettség nem terheli az ügyvédet, ha a bejelentés alapjául szolgáló adat, tény, körülmény büntetőeljárásban történő védelem, illetve bíróság előtti képviselet - ide nem értve a cégbírósági eljárásban történő képviseletet - előkészítése, ellátása során, vagy ellátását követően utóbb és azzal összefüggésben jutott tudomására, vagy a bejelentés alapjául szolgáló adat, tény, körülmény a fenti képviselet, védelem ellátásának, vagy az eljárás megindításának a szükségességével összefüggésben végzett jogi tanácsadás

\footnotetext{
${ }^{18}$ Pmt. 11. § (1) bekezdés
} 
során jutott a tudomására. Ezzel kapcsolatosan a FATF 40 ajánlásának 16. pontja rögzíti, hogy az ügyvédektől nem kell megkövetelni a gyanús ügyletek bejelentését, ha a vonatkozó információkat olyan körülmények között szerezték meg, amikor szakmai titoktartás kötelezettsége alatt vagy jogi szakmai kiváltsággal jártak el. Fontos azonban rögzíteni, hogy fenti esetekben csupán a bejelentési kötelezettség alól mentesül az ügyvéd, az ügyfél-átvilágítás alól nem.

Amennyiben a rendelkezésére álló adatok alapján az ügyvéd arra a következtetésre jut, hogy a megbízás teljesítése jogszabályba ütközne, vagy jogszabály megkerülésére irányulna, a megbízás teljesítését a bejelentéssel egyidejüleg meg kell tagadnia. Ha ilyen körülmények nem állnak fenn, az ügyvéd a bejelentéssel érintett megbízás teljesítését a bejelentésnek a pénzügyi információs egységhez való érkezésétől számított négy munkanapra felfüggeszti, amely határidő három munkanappal meghosszabbítható. A felfüggesztett megbízás ezen határidőn belül is teljesíthető azonban, ha a pénzügyi információs egység a kijelölt felelös személy útján az ügyvédet arról értesíti.

Az ügyvéd tekintetében - jóhiszemüség esetén - a bejelentés megtétele nem eredményezi jogszabály vagy szerződés által adatközlés vonatkozásában elöírt korlátozás megszegését, illetve nem keletkeztet polgári jogi vagy büntetőjogi felelősséget akkor sem, ha a bejelentés megtétele utóbb megalapozatlannak bizonyul.

A bejelentés és az adatszolgáltatás teljesítéséről, annak tartalmáról, az elemzőértékelő tevékenységről, az ügylet teljesítésének a felfüggesztéséről, a bejelentő személyéről, valamint arról, hogy az ügyféllel szemben indult-e büntetőeljárás, az ügyfélnek, illetve harmadik személynek, szervezetnek a bejelentő, a pénzügyi információs egység, valamint a megkeresett szerv tájékoztatást nem adhat, és köteles biztosítani, hogy a bejelentés megtörténte, annak tartalma és a bejelentő személye titokban maradjon (felfedés tilalma). A tilalom ugyanakkor nem vonatkozik a felügyeletet ellátó szerv bejelentő általi tájékoztatására. Nem vonatkozik továbbá a tilalom ügyvédek esetében az ügyfél tájékoztatására arra vonatkozóan, hogy az ügyfél által végrehajtott vagy végrehajtandó ügylet jogszabályi rendelkezések megsértését eredményezi.

Az ügyvédeket terhelő szigorú titoktartási szabályok alól törvényi szintű felmentést tartalmaz a Pmt. 75. § (5) bekezdése, amikor rögzíti, hogy az ügyvéd bejelentési kötelezettségének, valamint a pénzügyi információs egység megkeresésének teljesítése nem tekinthető a törvényen alapuló titoktartási kötelezettség megsértésének. Ennek indoka a jogállamiság alkotmányos követelményéből levezethető búnmegelőzési érdek, hiszen az ügyvédi titoknak minősülő adat, körülmény bejelentésének célja bűncselekmény, konkrétan pénzmosás megelözése. ${ }^{19}$

Fontos utalnunk arra is, hogy a bejelentési kötelezettség elmulasztása büntetőjogi következményekkel jár, ebben az esetben a Btk. 401. §-ban szabályozott, a pénzmosással kapcsolatos bejelentési kötelezettség elmulasztásának vétsége valósul meg.

\footnotetext{
19 Pénzmosás elleni szabályozás - gyakorlati útmutató. www.bpugyvedikamara.hu/szabalyozas/penzmosas-elleni-szabalyok Letöltve: 2020. március 24.
} 
Érdekes szemléltetni, hogy a kamarákhoz érkezett bejelentések száma viszonylag alacsony, a NAV éves jelentése szerint 2019. évben 3, 2018. évben 11, 2017. évben 4, 2016. évben 3, 2015. évben 2, 2014. évben 6, 2013-2012. években 3-3, 20112010. években 7-7 bejelentés érkezett ügyvédektól.

2.7. Nyilvántartás és iratmegőrzés. Az ügyvéd olyan ügyben, amelyben a jogi képviselet kötelező, a legalább személyazonosításra alkalmas okmány megtekintése útján azonosított természetes személyekről|20, a jogi személyekről és más szervezetekrő| ${ }^{21}$ a jogügyletek biztonságának elősegítése, továbbá az ügyvédi tevékenység korlátainak az érvényesítése érdekében, valamint a megbízás alapján ellátott ügyekrő| ${ }^{22}$ nyilvántartást vezet. Rögzíthető tehát, hogy azon túlmenően, hogy az ügyfél adatait az ügyvéd rögzíti az ügylet alapját képező okiratokban, rögzítenie kell az ügyfél-átvilágítás céljából rendszeresített nyomtatványon, valamint a fentiekben meghatározott nyilvántartásban, ezen túlmenően pedig az ügylet adatait is rögzítenie kell az ügyekről vezetett nyilvántartásában, így a pénzmosás megelőzésével kapcsolatos kötelezettségek teljesítése nem kevés adminisztrációval jár. Ha az ügyvéd a nyilvántartásban feltüntetett adatok változását állapítja meg, a megváltozott adatokat az ellenőrzés időpontjának feltüntetése mellett úgy rögzíti, hogy a korábban nyilvántartott adat utólag is megismerhető maradjon.

Az ügyvéd a Pmt.-ben foglalt kötelezettsége teljesítése során birtokába jutott személyes adatokat, személyes adatnak nem minősülő adatokat, beleértve az elektronikus azonosítás során birtokába jutott adatokat is, valamint minden egyéb, az üzleti kapcsolattal összefüggésben keletkezett adatot, az üzleti kapcsolattal összefüggésben keletkezett minden iratot, illetve azok másolatát az üzleti kapcsolat megszűnésétől, illetve az ügyleti megbízás teljesítésétől számított nyolc_évig jogosult kezelni. ${ }^{23}$

2.8. Belső szabályozás. Ha az ügyvéd alkalmazottat foglalkoztat, úgy szükséges belső ellenőrző és információs rendszer kialakítása is, hogy az alkalmazottat informálja a teljesítendő kötelezettségek köréről, illetve az ügyvédet tájékoztassa az alkalmazott által végzett tevékenységről. A pénzmosás megelőzésével kapcsolatos kötelezettségek körébe tartozó feladatok teljesítésére a szolgáltató köteles belső szabályzatot is készíteni. A Szabályzat 1.4. pontja szerint egyéni ügyvéd és egyszemélyes ügyvédi iroda esetében a Szabályzat egyben belső szabályzatnak és kockázatértékelésnek is minősül, így nincs szükség külön belső szabályzat készítésére és elfogadására. Az ügyvéd köteles gondoskodni arról is, hogy tevékenységének ellátásában részt vevő foglalkoztatottjai a pénzmosás megelőzésére és megakadályozására vonatkozó jogszabályi rendelkezéseket megismerjék, a pénzmosást lehetővé tevő, illetve megvalósító üzleti kapcsolatot, ügyletet felismerjék, a pénzmosásra utaló adat, tény, körülmény felmerülése esetén a törvénynek megfelelően tudjanak eljárni.

\footnotetext{
${ }^{20}$ Tartalmi elemeit az Üttv. 33. § (2) bekezdése határozza meg.

${ }^{21}$ Tartalmi elemeit az Üttv. 33. § (4) bekezdése határozza meg.

22 Tartalmi elemeit az Üttv. 53. § (2) bekezdése határozza meg.

${ }^{23}$ Pmt. 56-57. §
} 


\section{Kockázat alapú szemléletmód - kockázatértékelés}

A compliance célja a szabálytalan müködésből eredő kockázatok azonosítása, kezelése, csökkentése. Témánk szempontjából a kockázat alapú szemléletmód lényege, hogy valamennyi, az ügyvédi tevékenység során felmerülő tényezőt aszerint kell vizsgálni, hogy jelent-e az ügyvédre pénzmosási kockázatot. Az ügyvédi iroda kockázati profilját alapvetően az ügyfélköre és az iroda által gyakorolt ügyvédi tevékenység jellege határozza meg. Az ügyvéd az ügyfelet a Pmt. alapján átlagos, magas vagy alacsony kockázati szintbe sorolja. Az ügyvéd a belső kockázatértékelés elkészítéséhez, továbbá a kockázatok csökkentése és kezelése érdekében köteles figyelembe venni a nemzeti kockázatértékelés eredményét. ${ }^{24} \mathrm{~A}$ korábbi kamarai szabályzatokban a teljesség igénye nélkül felsorolásra kerültek az egyes ügyvédi tevékenységekkel kapcsolatos magas kockázati tényezők, melyeket a jelenlegi szabályzat már nem tartalmaz, azonban azok álláspontom szerint továbbra is figyelembe veendő körülmények.

Magas kockázati tényező lehet például ha a társaság alapítására vagy részesedés megvásárlására vonatkozó ajánlat olyan személyek részéről, akik láthatóan alkalmatlanok a társaság vezetésére, vagy akik felismerhetően kívülállók irányításával járnak el, vagy korábban bejegyzett, de tartósan nem működő veszteséges cégek felvásárlása történik nyilvánvalóan müködtetési cél nélkül, továbbá ingatlan adásvétele során az eladó vagy a vevő elfogadható magyarázat nélkül a készpénzfizetéshez ragaszkodik, vagy az ingatlan vételára minden különösebb indok nélkül feltűnően eltér - magasabb - a helyben szokásos közismert ártól, esetleg a felek lakcíme, tartózkodási helye és az ingatlan fekvése az ügyvéd irodájától távol fekszik, és az ügyvédválasztásnak semmilyen különös indoka nincs (pl. az ügyvéd korábban valamely fél megbízásából már eljárt).

A IV. Pénzmosási Irányelv ${ }^{25}$ rögzíti, hogy az új technológiák idő- és költséghatékony megoldásokat kínálnak mind a vállalkozások, mind az ügyfelek számára, és ezért a kockázatértékelés során célszerű figyelembe venni őket. Az illetékes hatóságoknak és a kötelezett szolgáltatóknak proaktívan kell fellépniük a pénzmosás új és innovatív módszerei ellen. A pénzmosásnak és a terrorizmus finanszírozásának a kockázata nem minden esetben ugyanolyan mértékü, ennek megfelelöen teljes körü kockázatalapú megközelítést kell alkalmazni. A kockázatok jellege változó, a változók pedig önmagukban vagy egymással ötvözve növelhetik vagy csökkenthetik a felmerülő potenciális kockázatot, és ennek folytán hatással vannak a megelőző intézkedések, például az ügyfél-átvilágítási intézkedések megfelelő szintjére. Az ügyféllel és az általa adott megbízással kapcsolatos kockázat felmérésénél a következőkre kell figyelemmel lenni:

- együttmüködik-e mindenben az ügyfél az azonosítás során, az átadott iratok hitelesen igazolják-e a személyazonosságot,

- átlátható és okszerü-e az ügyleti megbízásban kialakítani kért tulajdonosi szerkezet,

\footnotetext{
${ }^{24}$ Pmt. 27. § (6) bekezdés

${ }^{25}$ Preambulum 19.; 22.; 30-31. pont
} 
- felmerül-e a megbízás során olyan ügyvédi tevékenység, amely magasabb kockázatot jelenthet,

- kiterjed-e az ügyleti megbízás olyan vagyon kezelésére, amely a megbízással nem hozható összefüggésbe.

\section{4. Ügyvédi felelősség a pénzmosás elleni szabályok megszegése miatt}

Megállapítható, hogy az ügyvédeket meglehetősen összetett és speciális feladat terheli a pénzmosás megelőzésére irányuló kötelezettség teljesítése során. Az ügyvédet terhelő kötelezettségek közül a bejelentési kötelezettség elmulasztása búncselekménynek, ezen kívül valamennyi egyéb kötelezettség - így az ügyfélátvilágítás, nyilvántartás, iratmegőrzés, belső szabályozás - megszegése fegyelmi vétségnek minősül.

\subsection{A pénzmosással kapcsolatos bejelentési kötelezettség} elmulasztásához füződő büntetőjogi jogkövetkezmények. Aki a pénzmosás és a terrorizmus finanszírozásának megelőzésével és megakadályozásával kapcsolatos, törvényben előirt bejelentési kötelezettségének nem tesz eleget, vétség miatt akár két évig terjedő szabadságvesztéssel is büntethető. ${ }^{26}$ Bár a köztudatban a két fogalom gyakran összemosódik, a bejelentési kötelezettség nem jelent feljelentési kötelezettséget. A bejelentési kötelezettség tágabb a feljelentési kötelezettségnél, mivel nemcsak a pénzmosást, hanem az arra utaló gyanús körülményeket is jelenteni kell. A bejelentési kötelezettség teljesítésekor nem kell elérni az alapos gyanú szintjét, annál alacsonyabb bizonyosság is elegendő a kötelezettség teljesítéséhez.

4.2. Egyéb kötelezettségszegés, fegyelmi vétség. Az ügyfél-átvilágítással kapcsolatos, nyilvántartási és iratmegőrzési kötelezettség, valamint belső szabályozási kötelezettség megsértése, elmulasztása esetén fegyelmi felelősség terheli az ügyvédet. Az ügyvéd foglalkoztatottja vagy akár ügyfele is írásban értesítheti a területi ügyvédi kamarát a pénzmosás megelőzésére irányuló kötelezettség ügyvéd általi megsértésére utaló körülmény esetén. Az értesítést a kamara a beérkezéstől számított harminc napon belül köteles megvizsgálni és dönteni a felügyeleti eljárás hivatalból való megindításának szükségességéről. A területi ügyvédi kamara a pénzmosás és terrorizmus finanszírozásának megakadályozásáról szóló rendelkezések megtartását kamarai hatósági ellenőrzés keretében ellenőrzi.

Ha a kamarai hatósági ellenőrzés során a pénzmosás és a terrorizmus finanszírozásának megelőzéséről és megakadályozásáról szóló rendelkezések megsértését állapítják meg, úgy fegyelmi eljárás megindításának és lefolytatásának van helye. Ennek során fegyelmi büntetésként írásbeli megrovás, kötelezés a jogsértés megszüntetésére és az annak megismétlésétől való tartózkodásra, legfeljebb 400.000.000.- Ft-ig terjedő pénzbírság, valamint kizárás is kiszabható. ${ }^{27}$

\footnotetext{
${ }^{26}$ Btk. 401. §

27 Üttv. 110. $\S(1)$ bekezdés a-d) pontjai alapján
} 
A jogerős vagy a jogorvoslatra tekintet nélkül végrehajthatóvá nyilvánított fegyelmi határozatot a területi elnökség a Pmt-ben foglalt kötelezettségek megsértése esetén köteles közzétenni a honlapján, oly módon, hogy abból legalább a szabály megsértésének vagy a hiányosságnak a jellegére, illetve a jogsértő személyére vonatkozó adatok, információk megismerhetőek legyenek. A területi elnökség a közzétett információk elérhetőségét a közzétételtől számított öt évig köteles biztosítani. A közzétételi kötelezettség teljesítését azonban a területi elnökség elhalaszthatja, illetve mentesülhet a kötelezettség teljesítése alól abban az esetben, ha a jogsértő személyére vonatkozó adatok, információk nyilvánosságra kerülése aránytalan hátrányt okozna az érintett számára; a szabály megsértésének vagy a hiányosságnak a súlyára tekintettel az aránytalan lenne; vagy az a hatósági eljárás megindítását vagy a már megindított eljárás lefolytatását veszélyeztetné. ${ }^{28}$

\section{Záró gondolatok}

Összegzésképpen megállapítható, hogy a pénzmosás megelőzésével kapcsolatosan kiemelt szerep jut az ügyvédeknek. Az ügyvédek igénybevétele pénzmosási szándék esetén könnyen elérhető, hiszen a kapcsolatfelvétel gyors és közvetlen, viszonylag alacsony költségekkel jár, mely vonzó lehet a bűnelkövetői kör számára. Kiemelkedő jelentősége van a pénzmosás megelőzésével kapcsolatos teljes körü és pontos ismereteknek az ügyvédek részéről, valamint a kockázatot tartalmazó körülmények felismerésének, hiszen ezek nélkül képtelenség teljesíteni az ügyvédekre háruló, pénzmosás megelőzésére irányuló kötelezettséget. ${ }^{29}$

Fentiekre tekintettel álláspontom szerint szükséges lenne az ügyvédek számára a folyamatos, a változó szabályokhoz igazodó, a pénzmosás megelőzésével és megakadályozásával kapcsolatos gyakorlati útmutató közzététele, a tagság folyamatos tájékoztatása, nyilatkozat-minták, kockázat-értékelések folyamatos biztosítása, melyek véleményem szerint nagyban megkönnyítenék az ügyvédi tevékenységet és nyomatékosabban felhívnák az ügyvédek figyelmét a jogszabályban rögzített szigorú kötelezettségekre és azok elmulasztásának következményeire. Végkövetkeztetésként rögzíthető, hogy a pénzmosás compliance megfelelő működése nagymértékben hozzá tud járulni a pénzmosás elleni eredményes küzdelemhez, ${ }^{30}$ ugyanakkor az ügyvédeket terhelő kötelezettségek teljeskörü és pontos ismerete, ennek érdekében az ügyvédek folyamatos tájékoztatása, információkkal való ellátása álláspontom szerint elengedhetetlen a pénzmosás compliance megfelelő müködéséhez.

28 Üttv. 110. § (4) bekezdés

${ }^{29}$ Pénzmosás elleni szabályozás - gyakorlati útmutató.

http://www.bpugyvedikamara.hu/szabalyozas/penzmosas-elleni-szabalyok/ Letöltve: 2020. március 24.

30 Jacsó Judit: A pénzmosás compliance hazai és európai dimenzióban a társadalmi innováció tükrében; In: Miskolci Jogi Szemle 2019/2. különszám 1. kötet 412.o. 